\title{
A Comparison of Governance Challenges in Forest Restoration in Paraguay's Privately-Owned Forests and Madagascar's Co-managed State Forests
}

\author{
Stephanie Mansourian ${ }^{1, *}$, Lucy Aquino ${ }^{2}$, Thomas K. Erdmann ${ }^{3}$ and Francisco Pereira ${ }^{2}$
}

1 Mansourian Environmental Consultancy, 36 Mont d'Eau du Milieu, 1276 Gingins, Switzerland

2 WWF Paraguay, Avenida Argaña c/ Peron, Edificio Opa Rudy, 4to Piso, Asuncion, Paraguay; E-Mails: laquino@wwf.org.py (L.A.); fpereira@wwf.org.py (F.P.)

3 Environment, Climate Change \& Urban Services, DAI Solutions, 7600 Wisconsin Avenue, Suite 200, Bethesda, MD 20814, USA; E-Mail: Tom_Erdmann@dai.com

* Author to whom correspondence should be addressed; E-Mail: smansourian@infomaniak.ch; Tel.: +4179-6338839.

Received: 20 January 2014; in revised form: 18 March 2014 / Accepted: 28 March 2014 / Published: 21 April 2014

\begin{abstract}
Governance of forest restoration is significantly impacted by who are the owners of and rights holders to the forest. We review two cases, Paraguay's Atlantic forest and Madagascar's forests and shrublands, where forest restoration is a priority and where forest ownership and rights are having direct repercussions on forest restoration. In Paraguay where a large proportion of forests are in the hands of private landowners, specific legislation, government incentives, costs and benefits of forest restoration, and the role of international markets for commodities are all key factors, among others, that influence the choice of private landowners to engage or not in forest restoration. On the other hand, in Madagascar's co-managed state forests, while some similar challenges exist with forest restoration, such as the pressures from international markets, other specific challenges can be identified notably the likely long term impact of investment in forest restoration on land rights, traditional authority, and direct links to elements of human wellbeing. In this paper, we explore and contrast how these different drivers and pressures affect the restoration of forests under these two different property regimes.
\end{abstract}

Keywords: governance; forest restoration; Paraguay; Madagascar; Atlantic Forest 


\section{Introduction}

Forest restoration is increasingly being seen as an option to combat the degradation, loss and fragmentation of tropical forests. In the Atlantic forest of Paraguay and the moist forests of Madagascar, reforestation and forest restoration have been used as tools to counter forest loss. While reforestation refers to the return of trees to a previously forested land, it is frequently associated with the use of exotic species (e.g., [1,2]). On the other hand, forest restoration aims to recover most or all of a reference ecosystem. The Society for Ecological Restoration defines restoration as "the process of assisting the recovery of an ecosystem that has been degraded, damaged, or destroyed" [3]. Increasingly, many restoration projects focus on restoring ecosystem services [4], which may not always correspond to reference ecosystems or lead to improvements in biodiversity. Yet, natural forests composed of indigenous species are more adapted to local climatic conditions, provide local animal species with their native habitat, are more resilient and have traditionally been used by local inhabitants as a source of numerous products and services (e.g., [2,5-7]). The success or failure of forest restoration is frequently associated with underlying governance challenges, which are all too often overlooked.

Governance of forests (and natural resources more generally) encompasses a range of dimensions, notably related to who takes decisions, how these are taken and what mechanisms exist for effective decision-making related to natural resources (e.g., [8]). In small areas with clear property rights and a single landowner (state or other), decisions are somewhat easier to take although they may be complicated by underlying conflicting land claims (e.g., [5,7]). However, in larger areas (landscapes) where different land owners and users are involved, governance issues become more complex (e.g. $[9,10])$.

Legal forest ownership can be categorized as public or private, with community ownership and traditional ownership straddling these classifications. Management of forests can also be further sub-categorized as community, private, government, or co-managed [5,11]. Globally approximately $80 \%$ of forests are publicly owned, while $17.8 \%$ are privately owned and $2.2 \%$ classified as under "other" ownership [12]. These figures hide regional differences and conflicting claims over recognition of land and forest rights [13]. In 2002, a review by White and Martin [14] provided the following figures: $77 \%$ owned and administered by governments, 4\% reserved for communities, $7 \%$ owned by local communities, and approximately $12 \%$ owned by individuals. In 2008 , a further review [13] demonstrated that for 25 of the top 30 forested countries (covering $80 \%$ of the global forest estate) there was a reduction in state-owned forests (to 74\%) with the remainder shared between communities, individuals and firms. Furthermore, management responsibilities are also slightly different with $80 \%$ of forests managed by the state, while private corporations and institutions manage $10 \%$ of the world's forests and communities manage 7\% [12]. A general trend towards decentralization of forest management can be seen globally [15] which may or may not facilitate the claims of forest-dependent communities [13]. Unclear tenure appears to be an important cause of failure in managing (and restoring) forests [16]. We explore how different governance challenges appear exacerbated or complicated under different forest tenure arrangements leading to more or less effective forest restoration in Paraguay's Atlantic forest and Madagascar's forest and shrublands ecoregion. 


\section{Experimental Section}

\subsection{Methodology}

The objective of this work is to compare and contrast the different factors influencing the success (or failure) of forest restoration under two different property regimes in two of the world's biodiversity hotspots. In Paraguay, the focus is on private forests and in Madagascar on forests that are co-managed by the State and local community associations. Furthermore, in both cases, forest restoration is undertaken as one of the components of forest management (rather than a standalone priority). We compared the importance and threats to forests in Madagascar and Paraguay in order to understand the emergence and role of forest restoration. In particular, we looked at recent (twentieth and twenty-first century) historical changes in forest cover, land use, and relevant legislation (specifically, incentives and policies or policy frameworks related to forest management, use and restoration).

Our approach relied on an extensive literature review. A number of interviews were undertaken either by phone, Skype or face to face in Spanish and French to corroborate some of our findings and to add to our dataset. Interviewees were selected because of their direct experience in implementing forest restoration activities and/or forest co-management contracts (Madagascar) or because they were landowners undertaking forest restoration (Paraguay). Interview questions can be found in Appendix 1 . This paper also builds on direct field work by three of the authors.

\subsection{Framing Governance of Forest Restoration}

The success or effectiveness of forest restoration is influenced by a range of factors, including policies, incentives, land tenure, and markets, to cite just a few. It is also influenced by actors at all levels, from local to international. Several environmental governance frameworks exist which can be adapted to forest restoration. Lemos and Agrawal [8], for instance, highlight that environmental governance equates to interventions aiming at "changes in environment-related incentives, knowledge, institutions, decision making, and behaviors". They also identify the importance of the mechanisms, processes, regulations and organizations in governance to influence environmental outcomes. For Kishor and Rosenbaum [16] forest governance relates to "the norms, processes, instruments, people, and organizations that control how people interact with forests." Authority, power and capacity are three key dimensions considered by USAID [10] for effective natural resource governance. Davis et al. [17] refer to "actors" (including people and institutions), "rules" (including policies and laws) and "practices", as three essential components of forest governance. In this paper, we use a similar framework (see Figure 1) adapted from Mansourian and Oviedo [18] to explore, compare and contrast the governance factors that influence forest restoration in Madagascar and Paraguay. 
Figure 1. Framework to Assess the Governance of Forest Restoration (adapted from [18]).

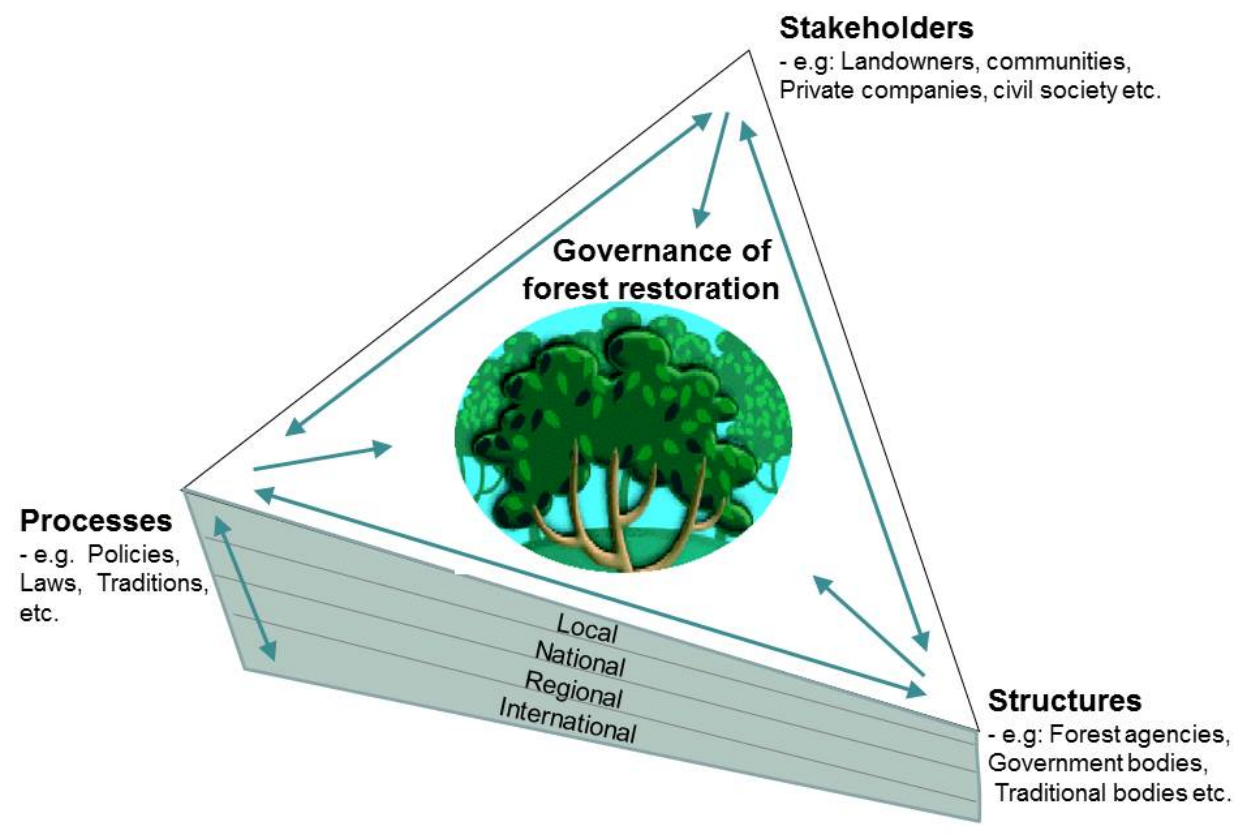

The framework proposed considers three essential factors when exploring the governance of natural resources, and in this particular case, the governance of forest restoration, these are: processes, stakeholders and institutions. "Processes" include policies, laws, strategies and all relevant rules. For example, in the context of forest restoration, processes might include laws related to land tenure or subsidies for planting different species. "Structures" in this framework include different agencies and other relevant bodies that help to organize stakeholders. In the context of forest restoration, this could be research bodies or implementing agencies, for example, local community groups or at a different scale, the national forest service. As to "stakeholders", in the context of forest restoration they may be local communities, individual landowners, private companies, and the government, amongst others. While the three dimensions impact on forest governance, they also inter-relate (see arrows in the diagram) in ways that may either complicate or simplify forest governance. For example, if representative bodies exist (under the "structures" dimension), communities (under the "stakeholders" dimension) may voice their needs and aspirations more effectively, thus leading (potentially) to these needs being better integrated into forest restoration, and overall, to better forest governance. All three dimensions of the framework provide essential foundations for successful restoration. Furthermore, they can be found at different scales, from local to international (also see for e.g., [19]). It can be argued that effective governance that supports forest restoration requires that all three dimensions be functioning optimally and also that the interactions between them function effectively. Although the emphasis in this paper is on the "processes" dimension, the other two dimensions are also considered.

\subsection{Study Sites}

Both Paraguay and Madagascar harbor two of the world's biodiversity hotspots as described by Myers et al. [20] and priority global ecoregions [21]: the Atlantic forest ecoregion (Argentina, Brazil and Paraguay) and Madagascar's forest and shrublands ecoregion. The specific zones explored in this 
paper are the Oriental Region of Paraguay (north and southeastern part of the country) and the moist tropical forest zone of Madagascar (eastern half of the island) (see maps in Figure 2).

Figure 2. Forest cover of Paraguay and Madagascar.

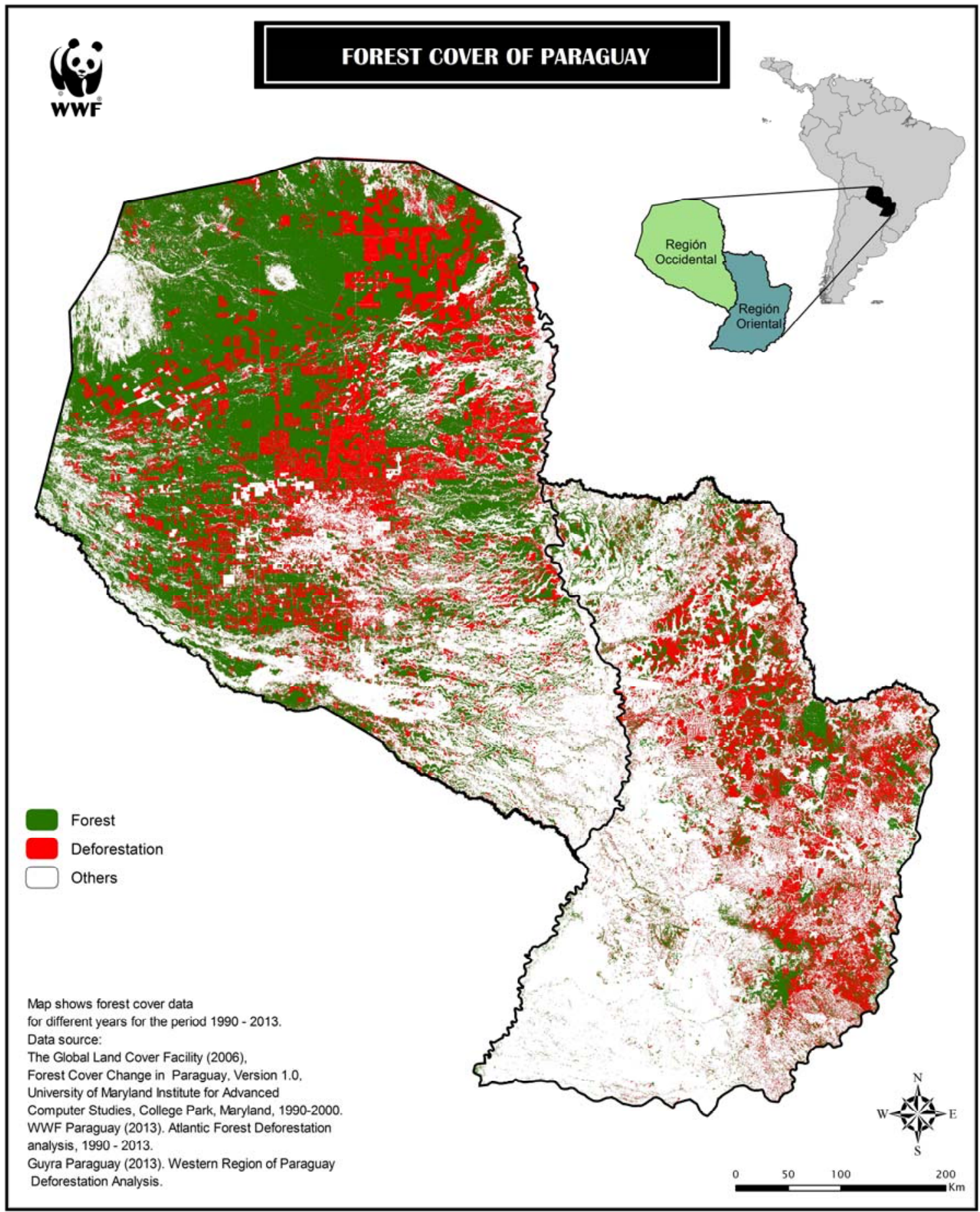


Figure 2. Cont.

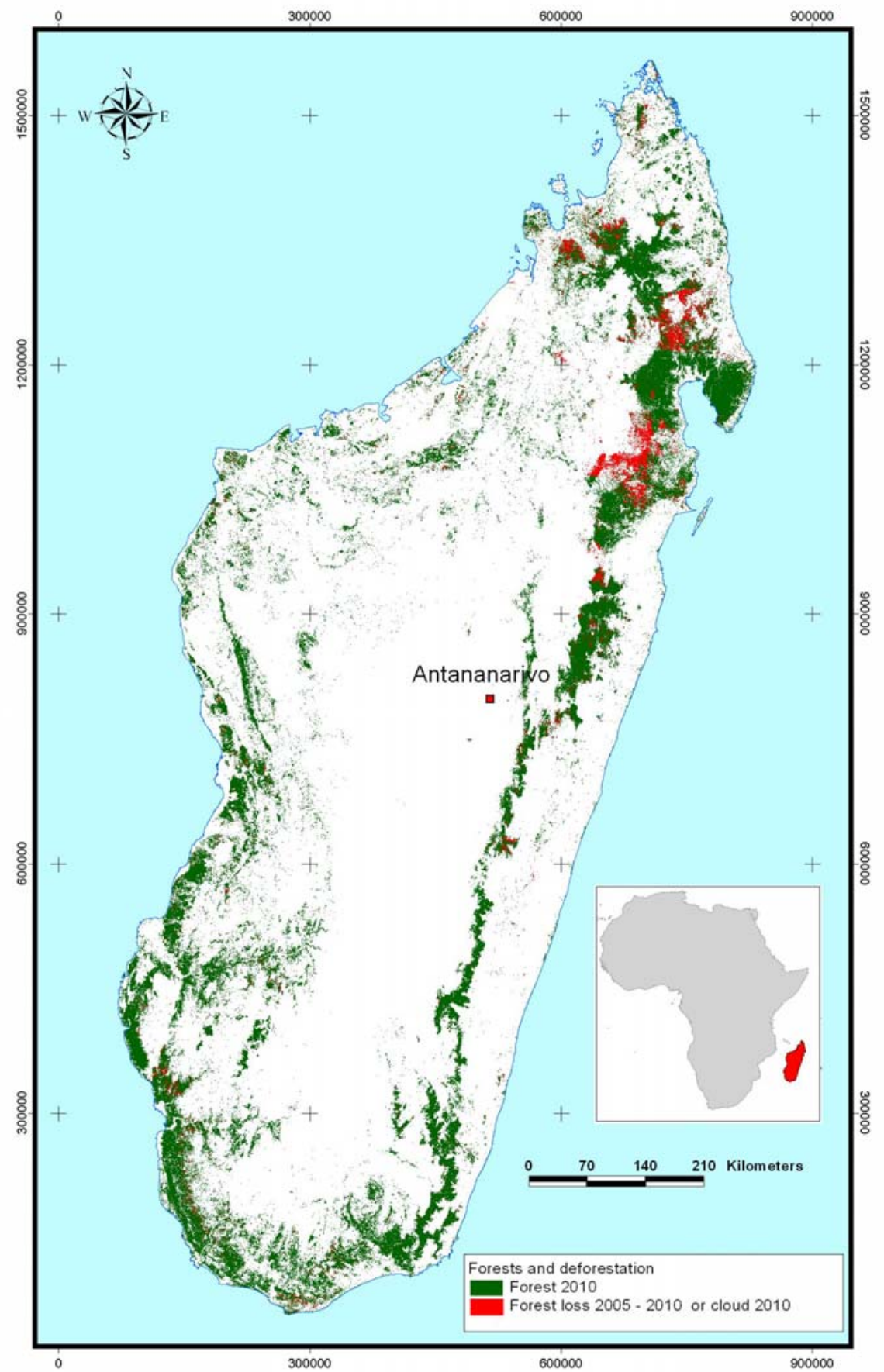

Source: Office National pour l'Environnement, Madagascar [22].

Economically, Paraguay is classified by UNDP's Human Development Index as medium development (rated 111th out of 186 countries) while Madagascar is classified as a low development country rated 151st [23]. Both countries have suffered from high rates of deforestation in the last decade, with Paraguay's deforestation rate averaging 16\% between 1999 and 2010, while Madagascar's was at a rate of $8 \%$ during the same period [23]. In terms of forest cover, Paraguay is classified as 44\% forest while Madagascar's land cover is $21.6 \%$ forest [23]. High deforestation rates have been fuelled in both countries by the economy increasingly relying on forest exploitation and 
conversion: in the case of Paraguay for energy, commercial agricultural and livestock [24-26], and in Madagascar both for energy and subsistence agriculture [27] (see Table 1).

Table 1. Forest Cover in Madagascar and Paraguay.

\begin{tabular}{|c|c|c|c|c|c|c|c|c|}
\hline \multirow{2}{*}{ Country } & \multicolumn{6}{|c|}{ Other Naturally } & \multicolumn{2}{|c|}{$\begin{array}{c}\text { Annual Rate of Change } \\
\text { in Forest (Total) 2005-2010 }\end{array}$} \\
\hline & 1000 ha & $\%$ of forest & 1000 ha & $\%$ of forest & 1000 ha & $\%$ of forest & 1000 ha/year & $\%$ \\
\hline Paraguay & 1850 & 11 & 15684 & 89 & 48 & n.s. & -179 & -0.99 \\
\hline Madagascar & 3036 & 24 & 9102 & 73 & 415 & 3 & -57 & -0.45 \\
\hline
\end{tabular}

Source: [12].

Other sources provide higher rates of deforestation for both Madagascar (for e.g., [28]) and Paraguay (for e.g., [25]).

\subsection{Overview of Forests in Each Ecoregion}

Madagascar's forests were estimated in 2005 by FAO [12] to be predominantly under public ownership (see below), while Paraguay was officially nearly two-thirds (61\%) under private ownership although the actual figure is considerably higher, estimated at over $90 \%$ (see for e.g., [29]). Of the $98 \%$ under public ownership in Madagascar, management rights for $2 \%$ have been devolved to communities. In addition, in Madagascar, of the $2 \%$ under private ownership, the majority (92\%) is owned by individuals, with $8 \%$ owned by local, indigenous and tribal communities [12] (see Table 2).

Table 2. Forest ownership in Madagascar and Paraguay.

\begin{tabular}{ccc}
\hline \multirow{2}{*}{ Country } & \multicolumn{2}{c}{ Ownership (2005) } \\
\cline { 2 - 3 } & Public & Private \\
\hline Madagascar & 98 & 2 \\
Paraguay & 39 & 61 \\
\hline
\end{tabular}

Source: [12].

\subsubsection{Paraguay's Atlantic Rainforest}

The Atlantic Forest ecoregion complex extends across the three South American countries of Paraguay, Argentina and Brazil. Only an estimated 11.7\% of the Atlantic forest's original area remains [30]. It consists of 15 distinct sub-ecoregions, with the one in Paraguay classified as Upper Paraná Atlantic Forest. The Atlantic forest is characterized by semi-humid forest with annual rainfall lower than $1700 \mathrm{~mm}$ and humid forest with rainfall between 1900-2000 mm. Paraguay's Upper Parana Atlantic Forest is home to an extremely varied flora including vascular plants, pteridophytes and bryophytes [31]. The forest is heavily fragmented, and restoring connectivity among forest fragments is a priority to improve functionality [30].

More than $97 \%$ of Paraguay's over six million inhabitants live in the Oriental region of the country, the area once dominated by the Atlantic Forest. While the Oriental Region makes up just $39 \%$ of the total land area of the country, the population density is disproportionately greater than in the rest of the 
country [32]. Massive loss and degradation of the forest can be attributed to demand for fuelwood, and agricultural and livestock development.

Until the mid-1960s Paraguay's eastern region remained largely untouched. Severe deforestation started in the 1960s and continued increasing in the 1970s with the so-called "green revolution", for the development of agriculture (cotton and soy) and the conversion of forest to exotic pasture for cattle ranching [33]. This was followed by extensive soy cultivation (with Paraguay being one of the world's leading soy exporters) [34].

\subsubsection{Madagascar's Forests and Shrublands Ecoregion}

Madagascar's forests and shrublands ecoregion is located along the eastern escarpment and coastal plain of the island. The ecoregion includes moist forests across an altitudinal range from sea level up to over 2000 meters (it includes: lowland rain forest ( 0 to $800 \mathrm{~m})$, moist montane forest (800 to $1300 \mathrm{~m}$ ) and sclerophyllous montane forest (1300 to roughly $2300 \mathrm{~m}$ ) [35]. These forests have long been recognized as an important center of endemism and diversity with hundreds of species of vertebrates and thousands of species of plants being strictly endemic to this ecoregion. All five families of endemic Malagasy primates can be found here, as can seven endemic genera of Rodentia, six endemic genera of Carnivora, and several species of Chiroptera [36].

Despite its importance, much of this habitat has been removed or fragmented (with an estimated 830 million ha being fragmented [27]). The predominant cause of deforestation is the local tradition of "tavy" or slash and burn agriculture (mainly for rainfed rice and cassava cultivation) which accounts for $80 \%$ of deforestation [27], although some [37] trace the process of deforestation back to the French occupation, particularly because of their logging concessions and cash crop plantations. Yet the Malagasy population is to a large extent (up to 70\% according to [27]) dependent on forests - both plantations and natural forests - for fuelwood and construction materials [38].

Plantations are dominated by exotic species in Madagascar, with pines, eucalypts, and wattles among the more common species; shade, ornamental, and fruit trees are also planted around settlements. These have been promoted through government efforts to reforest notably via state-owned plantations and land tenure incentives $[39,40]$.

\section{Results and Discussion}

The weight or importance attributable to different governance factors varies under different ownership and management systems for forests in the two case study countries and regions. Here we describe the key aspects of forest ownership and management in both countries and regions.

\subsection{Ownership and Management of Forests}

\subsubsection{Madagascar}

While much of Madagascar's land is under customary tenure arrangements, without deeds, titles, or cadastres [40], in actual fact customary tenure is rarely legally recognized [38]. Lack of clear tenure has been identified as one of the underlying causes of deforestation in Madagascar [41]. For example in the "payment for ecosystem services" project in Mantadia, the challenge identified by 
Wendland et al. [42] has been dealing with property rights since although most of the land is state-owned, individual and communal entitlements exist leading to conflicting land claims. Since 2005 a project to reform land tenure (Programme National Foncier-PNF or "national tenure program") has been in place, which could improve recognition of customary rights, although in the meantime the coup d'état has severely slowed such reforms. In addition, the program focuses on improving titling for agricultural land rather than forests [43].

Madagascar's attempts at improving community engagement in forest management started in 1996 with the creation of the GELOSE (Gestion Locale Sécurisée or "secure local management") law, which allows for the devolution of management rights of natural resources to rural communities. In 2001, a further decree established the Gestion Contractualisée des Forêts (GCF or "contractual management of forests") law, which defined the details of the contracts to transfer forest management rights and streamlined the GELOSE process [44].

Concretely, in co-managed forests three zones can usually be found: one under conservation where extraction is banned, one under sustainable management of resources for local community use, and a commercial zone. In some cases, a fourth restoration zone is designated. Groups of communities have to organize themselves in COBA (communautés de base or "local communities") associations to sign official management transfer contracts. These are initially valid for three years but can then be renewed. Contracts are negotiated between the central government, the commune and local communities [45]. To this day all the management contracts have been mediated by external agencies, such as international NGOs.

An estimated 750 co-management contracts have been signed since the start of this process for an area of more than 1.2 million hectares [46]. Furthermore, there has been a recognized growth in the capacity of communities to manage their forests more generally and to understand the stakes. According to Randrianarisoa et al. [47], in some areas under co-management deforestation has also been reduced although this has certainly not been the case across all areas under co-management. Recently, broader governance issues affecting the country have also had repercussions on environmental governance, including a marked increase in illegal logging [48].

\subsubsection{Paraguay}

In Paraguay in contrast, the majority of the nation's forests are privately owned $(61 \%$ according to FAO data [12] but closer to $90 \%$ according to other sources [29]. Land tenure remains one of the major causes of conflict in Paraguay.

Management of forests has been regulated by a number of laws, although in practice, there has been little enforcement [49]. Indeed, as highlighted by Contreras-Hermosilla [50] over-regulation characterizes much of Latin America's forestry sector, with in actual fact poor environmental outcomes. Ultimately, overly complex and multiple laws in the forest sector tend to lead to poor enforcement and alternative uses of land (notably for agricultural commodities) where legislation is more straightforward [51].

First and foremost, Paraguay still needs to develop an agrarian reform to distribute land equitably and implement land use planning. While multiple proposals have been made for reform, full reform (in 2001 the Agrarian Statute was amended to remove the consideration that forest lands are unproductive 
areas) has still not happened and landless peasants continue claiming land for agriculture and demanding an agrarian reform. Paraguay's Agrarian Statute of 1963 provided a perverse incentive for forest owners to clear land and put it under "productive use" lest this "unproductive land" be claimed by small farmers.

Since 1973, the Forest Law (Forestry Law 422/73) states that 25\% of all land should remain under forest cover. It also establishes fiscal incentives for reforestation [52]. However, loopholes exist in this law whereby by transferring the $25 \%$ to other owners, this area could be further cleared by $75 \%$. The result is that in the Eastern Region of Paraguay, forest cover is below 10\% on private land [53].

To help promote recovery of the Atlantic forest in compliance with Article 42 of Forest Law 422/73, the Conformance with Forest Law (CFL) program was recently created. This program constitutes a legal tool and market mechanism to help forest owners meet the required minimum $25 \%$ forest cover. For each property equal to or greater than 20 ha, the shortfalls or profits are calculated using satellite images (LANDSAT $5 \mathrm{TM}$ and C-BERS 2B, provided for free by the Instituto de Pesquisas Espaciais (INPE or the "institute of space research") of Brazil). Properties with an environmental shortfall are defined as those with the partial or complete absence of the $25 \%$ forest reserve cover and/or protective gallery forest along watercourses. In this way, environmental "profits" and "shortfalls" are quantified in terms of hectares of forest per district and per landowner. However, CFL can only be applied in areas where an up-to-date official register of land tenure is available. Currently only two political departments-Itapúa and Alto Paraná-fulfill this condition.

A further law (Law 4241 - Law on Protected Forests along Watercourses) was passed to encourage restoration of riverine forest. This law is promoted via the provision of saplings from tree nurseries, although quantities were limited and only five different species were provided as of 2004.

A law to promote reforestation (Ley No. 536 "Law to Promote Forestation and Reforestation") was enacted in 1995 establishing economic incentives and subsidies for forestry plantations with the government providing up to $75 \%$ of the direct costs of reforestation. However, the government has been unable to find the financial resources to maintain this program. In 2004, reforestation achievements were estimated to total approximately 40,000 hectares [53].

Sustainable forest management has been very limited in Paraguay (due to the high price of the certification process and the complicated bureaucracy involved) and currently there is only one Private Reserve (Ypeti) in the Atlantic Forest with FSC (forest stewardship council) certification. Illegal and legal forest management efforts have been very hard to tell apart in Paraguay and the government has failed to invest in supporting the forestry sector and protect landowners from unfair competition from illegal logging. To this day, the INFONA (The National Forestry Institute) does not have a sound system to record forest management operations [54]. As a result, private forest lands (and even protected areas) suffer severe degradation, and illegal conversion of forest is frequent, starting with selective logging induced by forest fire. Once the forest has been degraded, landowners disseminate exotic grass seeds that quickly dominate the area and the land is declared by the authorities as a cattle ranching area. Today this constitutes the most common process of deforestation in the Oriental Region of Paraguay.

A moratorium on deforestation was established since December 2004 in the Oriental Region of Paraguay, prohibiting clear cuts [55] which has now been renewed twice already until 2018. Even though this legislation helps to decrease the deforestation rate in the Oriental Region, degradation and 
illegal conversion continue by landowners, supported by the lack of will and even cases of corruption in the government.

The government, with the support of NGOs is now developing a protocol for Law 3001 (a "Payment for Environmental Services" law) that will pay landowners who conserve and protect their forest (additional to the required 25\%). The implementation of these payments is now being refined and may become a good incentive for landowners to engage in restoration on their land.

\subsection{Selection of Restoration/Reforestation Projects}

Through interviews and a literature review we identified some recent projects in Paraguay and Madagascar that included restoration or reforestation as one objective (see Table 3). In Madagascar, many of the projects involve payments for an ecosystem service such as biodiversity conservation or carbon sequestration (through REDD or another carbon-related mechanism). In Paraguay the protocol for payments for ecosystem services is still at an early stage and does not yet include restoration but rather avoiding deforestation.

A distinction is made for these projects between ownership and management, which is particularly relevant to Madagascar where co-management is in place on public forest land. Through interviews, we attempted to specify the principal aims of forest restoration in the two countries, the way it was undertaken and the challenges involved. Three main categories of aims for restoration (or reforestation sensu lato) were identified: ecological, socio-political and financial. Table 4 below summarizes our findings.

\subsection{Discussion}

It appears that success in ecological restoration remains limited in both countries given the continued rates of forest loss. In the face of this result, we explore the associated governance challenges. Taking the three dimensions of our forest governance framework, the processes dimension appears to be the most important in both country contexts. While the discussion focuses on this dimension, we also discuss the role of key stakeholder groups in the context of governance of forest restoration in Paraguay and Madagascar.

\subsubsection{Processes}

The main factors that appear to emerge from this case study comparison as being critical to forest restoration are related to tenure, management rights and incentives - all three falling under the "processes" dimension of our framework.

The role of land tenure within the framework of forest restoration and the pressure on forests in the context of tenure security or insecurity [51,56,57] is further highlighted through the above comparisons and study. In Paraguay, despite specific laws to promote reforestation and to stop deforestation in the Oriental Region, the country continues to face a high deforestation rate in both the Occidental and Oriental Regions [58] and limited success with restoration. This can be attributed to limited reach and capacity of the government to apply and enforce laws, many of which actually over-burden the sector. Wright et al. [59] also associate the high deforestation rate in the country with 
a high level of corruption. Subsidies in the agriculture sector further skew the value of forest conversion (e.g., see [50,51]). Finally, the soaring global demand for soy and beef within the context of tenure insecurity, high price of land and poor government regulation and enforcement, provide strong disincentives for forest restoration. However, increasing awareness combined with the involvement of financial entities in the sustainable development of the country, are putting pressure on producers to comply with the legislation in order to obtain their environmental licenses and be able to continue producing. For example, the government has prioritized the replication of the restoration projects that contribute to the legal mechanism "Conformance with the Forest Law" (CFL) currently being undertaken in four watersheds by the following public entities: SEAM, INFONA and the attorney general, with support from WWF.

In Madagascar on the other hand, a strong motivation by communities to engage in forest restoration is specifically the opportunity for enhanced tenure security (as emerged notably from our interviews). Through forest restoration (as well as improvements in forest management more generally), communities are empowered and recognized as rightful guardians of forests. Contracts established via the GELOSE or GCF mechanisms also help to secure titling and to exclude outsiders from the forest [57], thus reducing the risk of degradation and deforestation. Furthermore, in most cases, forest restoration in Madagascar is promoted via some form of payments (payment for ecosystem services, free seedlings through international projects etc.), providing an added incentive for communities to engage in forest restoration. For example, the Andasibe-Mantadia corridor project (see Table 3) provides payments to communities for both protecting and restoring the forest [60]. A final incentive in Madagascar that supports forest restoration is the reliance of communities on the provision of direct goods and services by the forest.

Regarding incentives, it is clear that, in both Madagascar and Paraguay, economics play a major role with respect to practicing restoration or not. In Paraguay, like in other parts of South America, restoration efforts must compete with lucrative agricultural commodities which are themselves promoted by subsidies [61], while in Madagascar, the household economy and the need to practice at least some subsistence agriculture impacts on decisions with respect to forest restoration. In both cases, economic incentives for restoration likely need to be increased in order to offer an alternative to the prevailing context.

Specific incentives that have influenced forest owners in both countries can be divided as legal, market, and financial. For example in Paraguay, legal incentives such as the requirement to set aside $25 \%$ of forest on private lands, combined with financial incentives, have encouraged private landowners to restore forests. At the same time, the high price of commodities such as soy has acted as a market disincentive in Paraguay, leading to forest conversion. In Madagascar, the provision of free seedlings to communities for them to engage in restoration in the Fandriana-Marolambo landscape has acted as an important incentive for them to not only restore the landscape but also to use a wider range of indigenous species. Payments for the ecosystem services of biodiversity conservation and carbon sequestration have been trialed in Madagascar (see examples in Table 3). Indeed, payments for ecosystem services, notably carbon sequestration and watershed protection, appear to be means that could enhance the appeal of forest restoration. For example, the REDD + mechanism that is increasingly gaining ground provides payments for protection, effective management and restoration of forests (e.g., [2]). 
Table 3. Projects involving restoration/reforestation for different objectives ${ }^{\text {a }}$.

\begin{tabular}{|c|c|c|c|c|}
\hline & Project & Aim/Type & Ownership & Management \\
\hline \multirow{7}{*}{ Madagascar } & $\begin{array}{l}\text { Makira-Makira Carbon Company (MCC) and } \\
\text { Wildlife Conservation Society (WCS) }\end{array}$ & REDD $^{b}$ & Public & $\begin{array}{l}\text { Management of Protected Area by International NGO; } \\
\text { co-managed outside of the protected area }\end{array}$ \\
\hline & Ankeniheny to Zahamena Forest Corridor (CAZ) - Conservation International & REDD & Public & Co-managed \\
\hline & Fandriana to Vondrozo Forest Corridor (COFAV) Conservation International & REDD & Public & Co-managed \\
\hline & Holistic Forest Conservation Programme (PHCF)—WWF and Good Planet & REDD & Public & Co-managed and Community management \\
\hline & FORECA-GTZ/Inter-cooperation & REDD & Public & $\begin{array}{l}\mathrm{REDD}^{+} \text {readiness initiative ( } 6 \text { of the } 8 \text { project sites were in } \\
\text { the forest and shrublands ecoregion) }\end{array}$ \\
\hline & Andasibe-Mantadia Biodiversity Corridor-Conservation International & Carbon sequestration & Public & Co-managed and Community management \\
\hline & WWF Fandriana Marolambo landscape & Ecological restoration & Public & Community management \\
\hline \multirow{8}{*}{ Paraguay } & $\begin{array}{l}\text { TFCA (Tropical Forest Conservation Act) with Guyra Paraguay: Restoration } \\
\text { of connectivity between two forest blocks in Caazapa National Park }\end{array}$ & Ecological restoration & Private & Debt swap board (includes NGOs and government) \\
\hline & $\begin{array}{l}\text { Restoration of four watersheds, developed by public entities: SEAM, } \\
\text { INFONA and attorney general, with support from WWF; } \\
\text { legal mechanism called "Conformance with the Forest Law" (CFL) }\end{array}$ & Ecological restoration & Private & Public \\
\hline & $\begin{array}{l}\text { ITAIPU bi-national: project called "Paraguay Biodiversity" with SEAM, } \\
\text { the World Bank and Partners: to restore the connectivity of six protected areas } \\
\text { and the ITAIPU Reserves along to the Parana River }\end{array}$ & Ecological restoration & Private & Public with support of NGOs \\
\hline & $\begin{array}{c}\text { Project called "Sustainable Management of Natural Resources." } \\
\text { Ministry of Agriculture (KFW/GTZ). To develop an Agroforestry programme with } \\
\text { small producers in the Oriental Region of Paraguay. }\end{array}$ & $\begin{array}{l}\text { Agroforestry using } \\
\text { mixed species }\end{array}$ & Community & Public \\
\hline & $\begin{array}{l}\text { Project of Conformance with the Forest Law. Coordinated by WWF, } \\
\text { to restore } 25 \% \text { of forest reserve. }\end{array}$ & Ecological restoration & Private & Private and Public \\
\hline & $\begin{array}{l}\text { Project: Restoring the Monday Watershed. Project developed by } \\
\text { Association "A Todo Pulmon Paraguay Respira”. }\end{array}$ & $\begin{array}{l}\text { Ecological and } \\
\text { Agroforestry }\end{array}$ & Private & Private \\
\hline & Restoration undertaken as a fine for those deforesting on their own land & Ecological restoration & Private & Public \\
\hline & Restoration of areas to comply with sugar certification scheme & Ecological Restoration & Private & Private \\
\hline
\end{tabular}

Notes: Sources: $[38,42,62,63] .{ }^{a}$ All in the two ecoregions being studied; Note that this list is not exhaustive but rather illustrative; ${ }^{\mathrm{b}}$ Reducing Emissions from Deforestation and Forest Degradation. 
Table 4. Restoration/reforestation aims, practices and challenges for governance in Paraguay's Privately-Owned Forests and Madagascar's Co-managed State Forests

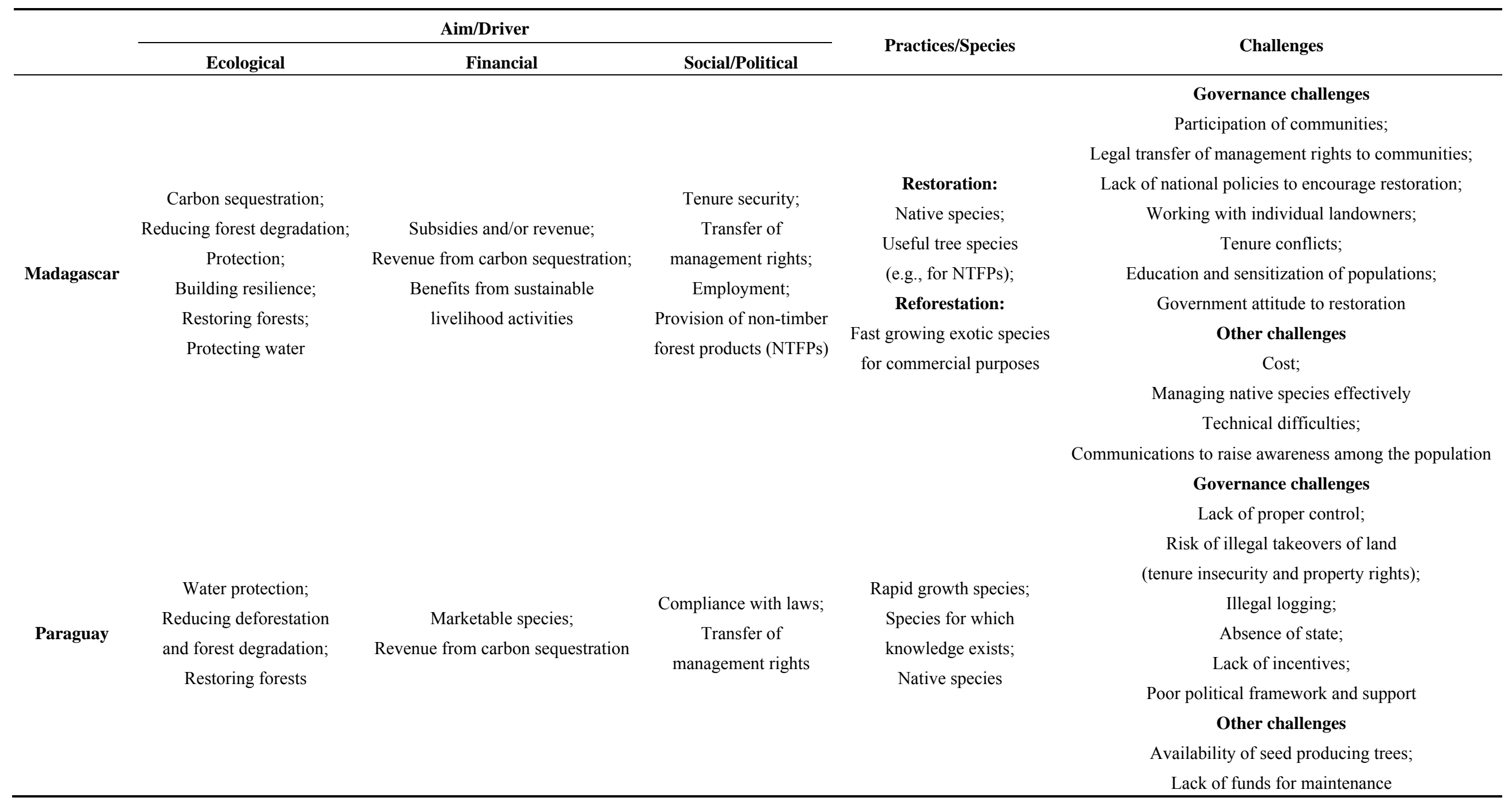




\subsubsection{Stakeholders}

In addition to the processes dimension, the capacity, engagement, accountability and recognition of stakeholder groups also have a significant impact on governance of restoration zones and activities. The interplay at different levels, from local stakeholders to international actors, plays an important role in the governance of forests $[56,64,65]$ and this can be seen with respect to forest restoration in both countries. For instance, in Paraguay, demand for soy from international players has a direct impact on local farmers' decisions to grow soy (at the cost of forest restoration). Equally in Madagascar, local communities' desire to recover their rights to manage forests is impacted by rules defined by national (and in some cases, such as the REDD+ mechanism, international) level players [65]. Furthermore, the role of "neutral" parties (such as international NGOs) appears critical in implementing management transfers in Madagascar (e.g., [66]). At the local level, tensions between local stakeholders, in particular communities or indigenous groups, versus private landowners, are particularly relevant in Paraguay (e.g., $[13,61]$ ) but also in Madagascar (e.g., [38,67]).

In both countries, the relative absence of the government forest service and the associated lack of enforcement of forest regulations have contributed to deforestation. In Madagascar, this has been counteracted to a certain extent by the empowerment of COBA associations which now have control of some forest areas, effectively curbing open access to these resources [44,67]. It appears that State authority and power have been largely absent in many areas in Paraguay's Atlantic Forest and Madagascar's forests and shrublands. Strengthening the presence of this key stakeholder group will likely lead to a more stable forest co-management regime in Madagascar and heightened respect for forest regulations and laws in Paraguay, ultimately enhancing restoration efforts.

We further argue that the lack of integration across levels (e.g., between local level structures and stakeholders and national processes and structures) as well as across the three dimensions of the framework (i.e., between processes, stakeholders and structures) impedes the creation of an adequate governance context that is conducive to successful forest restoration. For example in Paraguay, complex forest legislation is not matched by supportive institutions at both the national and local levels to implement and enforce such legislation. In Madagascar on the other hand, all too frequently the reason for local-level engagement in co-management arrangements around forests (with or without a restoration dimension) is triggered by poor national level policies related to management and ownership rights. Resolution therefore of all three dimensions of the governance framework and particularly focusing at the national and local levels, would help provide a more positive climate for effective forest restoration.

\section{Conclusions}

In conclusion, from a biodiversity perspective, the need for forest restoration in Paraguay's Atlantic Forests and Madagascar's forests and shrublands has been well established but success in this respect appears to be limited. One important factor contributing to this limitation is ongoing challenges related to governance. A three-pronged framework helped us to better understand the key issues and dimensions. Using this framework, it appears that the "processes" dimension of governance, which includes laws, strategies and incentives is particularly challenging, with poor policies and low 
implementation of the legislation. The "stakeholders" dimension, and in particular the interaction among stakeholders across different levels (from local to international), also appears to complicate effective governance of forest restoration in the two case studies.

The two case studies highlight that under different tenure arrangements, the governance challenges for forest restoration differed somewhat. So far, in Madagascar increased tenure security, provision of direct ecosystem goods and services, and payments for ecosystem services have been critical incentives for local community engagement in restoration. In contrast, in Paraguay, market pressures have provided a disincentive for forest restoration, and forest laws and regulations that favor restoration need to be applied with greater rigor. Nevertheless, in both cases weak government enforcement and remaining lack of clarity in tenure arrangements impede progress on forest restoration.

The present challenge in both countries lies in improving the forest governance context so that processes are more effective and key stakeholder groups can increase their participation in restoration activities. The lack of positive incentives is one of the main reasons for limited restoration activities, with the high prices of commodities being a significant disincentive for forest restoration. In both countries, enhanced economic incentives, such as payments for ecosystem services, are needed to contribute to a forest governance context that favors restoration.

\section{Acknowledgments}

The authors would like to thank the interviewees for taking the time to respond to our questions, Anjara Andriamanalina for designing the map of Madagascar, Menchi Garay for the map of Paraguay, Violeta Carrillo for helping with the bibliography for Paraguay, and the three anonymous reviewers and Anne Sgard for their valuable comments on an earlier draft.

\section{Author Contributions}

Stephanie Mansourian led on the general framework for the paper. Lucy Aquino contributed specific information on Paraguay while Francisco Pereira led on the interviews in Paraguay. Tom Erdmann contributed specific information on Madagascar and led on the interviews in Madagascar.

\section{Conflicts of Interest}

The views expressed represent those of the authors and do not necessarily represent those of their organizations.

\section{References}

1. Lamb, D.; Erskine, P.D.; Parrotta, J.A. Restoration of degraded tropical forest landscapes. Science 2005, 310, 1628-1632. 
2. Kapos, V.; Kurz, W.A.; Gardner T.; Ferreira, J.; Guariguata, M.; Pin Koh, L.; Mansourian, S.; Parrotta, J.A.; Sasaki, N.; Schmitt, C.B. Impacts of Forest and Land Management on Biodiversity and Carbon. In Understanding Relationships between Biodiversity, Carbon, Forests and People: The Key to Achieving REDD+ Objectives. A global Assessment Report; Parrotta, J., Wildburger, C., Mansourian, S., Eds.; IUFRO: Vienna, Austria, 2012; pp. 53-80.

3. Society for Ecological Restoration International Science \& Policy Working Group. The SER International Primer on Ecological Restoration. Available online: www.ser.org (accessed on 16 January 2014).

4. Bullock, J.M.; Aronson, J.; Newton, A.C.; Pywell, R.F.; Rey-Benayas, J.M. Restoration of ecosystem services and biodiversity: Conflicts and opportunities. Trends Ecol. Evolut. 2011, 26, 541-549.

5. Agrawal, A. Forests, governance, and sustainability: Common property theory and its contributions. Int. J. Commons 2007, 1, 111-136.

6. Dudley, N. Restoring Quality in Existing Native Forest Landscapes. In Forest Restoration in Landscapes: Beyond Planting Trees; Mansourian, S., Vallauri, D., Dudley, N., Eds.; Springer: New York, NY, USA, 2005.

7. Strassburg, B.N.; Vira, B.; Mahanty, S.; Mansourian, S.; Martin, A.; Dawson, N.M.; Gross-Camp, N.; Latawiec, A.; Swainson, L. Social and Economic Considerations Relevant to REDD+. In Understanding Relationships between Biodiversity, Carbon, Forests and People: The Key to Achieving REDD+ Objectives, a Global Assessment Report; Parrotta, J., Wildburger, C., Mansourian, S., Eds.; IUFRO: Vienna, Austria, 2012.

8. Lemos, M.C.; Agrawal, A. Environmental Governance. Annu. Rev. Environ. Resour. 2006, 31, $297-325$.

9. Görg, C. Landscape governance the "politics of scale" and the "natural" conditions of places. Geoforum 2007, 38, 954-966.

10. United States Agency for International Development (USAID). Guidelines for Assessing the Strengths and Weaknesses of Natural Resource Governance in Landscapes and Seascapes; United States Agency for International Development: Washington, DC, USA, 2013. Available online: http://www.frameweb.org/CommunityBrowser.aspx?id=10650 (accessed on 16 January 2014).

11. Borrini-Feyerabend, G.; Dudley, N.; Jaeger, T.; Lassen, B.; Pathak Broome, N.; Phillips, A.; Sandwith, T. Governance of Protected Areas: From Understanding to Action. Best Practice Protected Area Guidelines Series No. 20; International Union for Conservation of Nature: Gland, Switzerland, 2013; p. 124.

12. Food and Agriculture Organization of the United Nations. Forest Resources Assessment; FAO: Rome, Italy, 2010.

13. Sunderlin, W.D.; Hatcher, J.; Liddle, M. From Exclusion to Ownership? Challenges and Opportunities in Advancing Forest Tenure Reform; Rights and Resources Initiative: Washington, DC, USA, 2008.

14. White, A.; Martin, A. Who Owns the World's Forests; Forest Trends and Center for International Environmental Law: Washington, DC, USA, 2002.

15. Agrawal, A.; Chhatre, A.; Hardin, R. Changing governance of the world's forests. Science 2008, 320, 1460-1462. 
16. Kishor, N.; Rosenbaum, K. Assessing and Monitoring Forest Governance: A User's Guide to a Diagnostic Tool; Program on Forests (PROFOR): Washington, DC, USA, 2012. Available online: http://www.profor.info/node/1998 (accessed on 16 January 2014).

17. Davis, C.; Williams, L.; Lupberger, S.; Daviet, F. Assessing Forest Governance; World Resources Institute: Washington, DC, USA, 2013. (Available online at http://www.wri.org/publication/ assessing-forest-governance (accessed on 16 January 2014).

18. Mansourian, S.; Oviedo, G. Framework on Governance of Protected Areas and Livelihoods; International Union for Conservation of Nature: Gland, Switzerland, 2009; p. 25.

19. Pahl-Wostl, C. A conceptual framework for analysing adaptive capacity and multi-level learning processes in resource governance regimes. Glob. Environ. Chang. 2009, 19, 354-365.

20. Myers, N.; Mittermeier, R.A.; Mittermeier, C.G.; da Fonseca, G.A.B; Kent, J. Biodiversity hotspots for conservation priorities. Nature 2000, 403, 853-858.

21. Olson, D.M.; Dinerstein, E. The Global 200: A representation approach to conserving the earth's most biologically valuable ecoregions. Conserv. Biol. 1998, 12, 502-515.

22. Evolution de la Couverture de Forêts Naturelles à Madagascar 2005-2010; Office National pour l'Environnement, Direction Générale des Forêts, Foiben-Taosarintanin'i Madagasikara, Madagascar National Parks, Conservation International: Antananarivo, Madagascar, 2013; p. 48.

23. United Nations Development Programme. Human Development Report; UNDP: New York, NY, USA, 2013.

24. Cartes, L.C. Breve historia de la conservación en el Bosque Atlántico. In El Bosque Atlantico en Paraguay: Biodiversidad, Amenazas y Perspectivas; Asociación Guyra Paraguay, Conservation International: Asuncion, Paraguay, 2005; pp. 37-54.

25. Aide, T.M.; Clark, M.L.; Grau, H.R; Lopez-Carr, D.; Levy, M.A.; Redo, D.; Bonilla-Moheno, M.; Riner, G.; Andrade-Nuñez, M.J.; Muñiz, M. Deforestation and Reforestation of Latin America and the Caribbean (2001-2010). BIOTROPICA 2013, 45, 262-271.

26. Hansen, M.C.; Potapov, P.V.; Moore, R.; Hancher, M.; Turubanova, S.A.; Tyukavina, A.; Thau, D.; Stehman, S.V.; Goetz, S.J.; Loveland, T.R.; et al. High-resolution global maps of 21st century forest cover change. Science 2013, 342, 850-853.

27. Roelens, J.B.; Vallauri, D.; Razafimahatratra, A.; Rambeloarisoa, G.; Razafy, F.L. Restauration des paysages forestiers: Cinq ans de réalisation à Fandriana-Marolambo; WWF France: Paris, France, 2010; p. 90.

28. Grinand, C.; Rakotomalala, F.; Gonde, V.; Vaudryc, R.; Bernoux, M.; Vieilledent, G. Estimating deforestation in tropical humid and dry forests in Madagascar from 2000 to 2010 using multi-date Landsat satellite images and the random forests classifier. Remote Sens. Environ. 2013, 139, 68-80.

29. Fogel, R.B. La actual distribución de tierras en el Paraguay y el conflicto agrario; Documento Estudio N 4; BaseInvestigaciones Sociales: Asunción, Paraguay, 1989.

30. Ribeiro, M.C.; Metzger, J.P.; Martensen, A.C.; Ponzoni, F.J.; Hirota, M.M. The Brazilian Atlantic forest: How much is left, and how is the remaining forest distributed? Implications for conservation. Biol. Conserv. 2009, 142, 1141-1153. 
31. Di Bitetti, M.S.; Placci, G.; Dietz, L.A. A Biodiversity Vision for the Upper Parana Atlantic Forest Ecoregion: Designing a Biodiversity Conservation Landscape Priorities for Conservation Action; World Wildlife Fund: Washington, DC, USA, 2003; p. 104.

32. Paraguay Perfil Poblacional 2012. Available online: http://www.indexmundi.com/es/paraguay/ poblacion_perfil.html (accessed on 16 January 2014).

33. Macedo, A.M.; Cartes, J.L. Aspectos Economicos del BAAPA. In El Bosque Atlántico en Paraguay: Biodiversidad, Amenazas y Perspectivas; Cartes, J.L., Ed.; Asociación Guyra Paraguay, Conservation International: Washington, DC, USA, 2005, pp. 107-126.

34. Guereña, A. El Espejismo de la Soja: Los límites de la responsabilidad social empresarial; Oxfam: Oxford, UK, 2013; p. 55.

35. White, F. The Vegetation of Africa, a Descriptive Memoir to Accompany UNESCO/AETFAT Vegetation Map of Africa; United Nations Educational, Scientific and Cultural Organization: Paris, France, 1983.

36. Goodman, S.M.; Benstead, J.P. The Natural History of Madagascar; Chicago University Press: Chicago, IL, USA, 2003.

37. Jarosz L. Defining and explaining tropical deforestation: Shifting cultivation and population growth in colonial Madagascar (1896-1940). Econ. Geogr. 1993, 69, 366-379.

38. Ferguson, B. REDD comes into fashion in Madagascar. Madagascar Conserv. 2009, 4, 132-137.

39. Bertrand, A. The Spread of the Merina People in Madagascar and Natural Forest and Eucalyptus Stand Dynamics. In Beyond Tropical Deforestation; Babin, D., Ed.; UNESCO/CIRAD: Paris, France, 2004.

40. Kull, C.A.; Ibrahim, C.K.; Meredith, T. Can Privatization Conserve the Global Biodiversity Commons? Tropical Reforestation Through Globalization. Presented at International Association for the Study of Common Property, Bali, 19-23 June 2006.

41. Davis, C.; Daviet, F.; Nakhooda, S.; Thuault, A. A Review of 25 Readiness Plan Idea Notes from the World Bank Forest Carbon Partnership Facility, WRI Working Paper; World Resources Institute: Washington, DC, USA, 2009. Available online: http://www.wri.org/gfi (accessed on 16 January 2014).

42. Wendland, K.J.; Honzák, M.; Portela, R.; Vitale, B.; Rubinoff, S.; Randrianarisoa, J. Targeting and implementing payments for ecosystem services: Opportunities for bundling biodiversity conservation with carbon and water services in Madagascar. Ecol. Econ. 2010, 69, 2093-2107.

43. Ferguson, B. Madagascar. In REDD, Forest Governance and Rural Livelihoods: The Emerging Agenda; Springate-Baginski, O., Wollenberg, E., Eds.; CIFOR: Bogor, Indonesia, 2010.

44. Hockley, N.J.; Andriamarovololona, M.A., The economics of community forest management in Madagascar: Is there a free lunch? An analysis of Transfert de Gestion. USAID: Washington, DC, USA, 2007.

45. Babin, D.; Bertrand, A. Comment Gérer le Pluralisme: Subsidiarité et Médiation Patrimoniale. Unasylva 1998. Available online: http://www.fao.org/DOCREP/W8827F/w8827f05.htm\# comment gérer le pluralisme: subsidiarité et médiation part (accessed on 16 January 2014).

46. Anon, Ministère de l'Environnement et des Forêts, Antsiranana, Madagascar. Recommandations et Rapport d'Atelier, Journées Informatives et Prospectives sur les Transferts de Gestion des Ressources Naturelles. 2011, Unpublished work. 
47. Randrianarisoa, A.; Raharinaivosoa, E.; Koll, H.E. In proceedings of Des Effets De La Gestion Forestière par les Communautés Locales De Base A Madagascar: Cas d' Arivonimamo et de Merikanjaka sur les Hautes Terres de Madagascar; Workshop on Forest Governance \& Decentralization in Africa: Durban, South Africa, 8-11 April 2008.

48. Innes, J.L. Madagascar rosewood, illegal logging and the tropical timber trade. Madagascar Conserv. Dev. 2010, 5, 6-10.

49. Yanosky, A.; Cabrera, E. La capacidad Nacional de conservación del Bosque Atlántico. In Biodiversidad, Amenazas y Perspectivas; Cartes, J.L., Ed.; Asociación Guyra Paraguay, Conservation International: Asunción, Paraguay, 2005; pp. 137-172.

50. Contreras-Hermosilla, A. People, governance and forests-The stumbling blocks in forest governance reform in Latin America. Forests 2011, 2, 168-199.

51. McGinley, K.; Alvarado, R.; Cubbage, F.; Diaz, D.; Donoso, P.J.; Gonçalves Jacovine, L.A.; de Silva, F.L.; MacIntyre, C.; Monges Zalazar, E. Regulating the sustainability of forest management in the Americas: Cross-country comparisons of forest legislation. Forests 2012, 3, 467-505.

52. Vidal, V. Estudio sobre Mecanismos Financieros para el Manejo Forestal Sustentable en Sudamerica. Fase I. Cono Sur. FAO, 2004. Available online: http://www.rlc.fao.org/proyecto/ rla133ec/pag/i_paises.htm (accessed on 16 January 2014).

53. Chemonics International. Tropical Forestry and Biodiversity Conservation in Paraguay: Final Report of a Section 118/119 Assessment EPIQ II Task Order No.1; United States Agency for International Development: Asunción, Paraguay, 2004; p. 61.

54. Abed, S.R.; Santagada, E. Régimen Jurídico Forestal de la República del Paraguay. Análisis crítico: Compilación normativa; Instituto de Derecho y Economía Ambiental, Food and Agriculture Organization of the United Nations, Instituto Nacional Forestal: Asunción, Paraguay, 2011; p. 155.

55. WWF-Paraguay. Ending Deforestation: Lessons Learnt from WWF's Experience; WWF-Paraguay: Asuncion, Paraguay, 2007; p. 28.

56. Kanowski, P.J.; McDermott, C.L.; Cashore, B.W. Implementing REDD+: Lessons from analysis of forest governance. Environ. Sci. Policy 2011, 14, 11-117.

57. Jacoby, H.G.; Minten, B. Is land titling in sub-Saharan Africa cost-effective? Evidence from Madagascar. World Bank Econ. Rev. 2007, 21, 461-485.

58. Huang, C.; Kim, S.; Song, K.; Townshend, J.R.G.; Davis, P.; Altstatt, A.; Rodas, O.; Yanosky, A.; Clay, R.; Tucker, C.J.; Musinsky, J. Assessment of Paraguay's forest cover change using Landsat observations. Glob. Planet. Chang. 2009, 67, 1-12.

59. Wright, S.J.; Sanchez-Azofeifa, G.A.; Portillo-Quintero, C.; Davies, D. Poverty and corruption compromise tropical forest reserves. Ecol. Appl. 2007, 17, 1259-1266.

60. Jindal, R.; Swallow, B.; Kerr, J. Forestry-based carbon sequestration projects in Africa: Potential benefits and challenges. Nat. Resour. Forum 2008, 32, 116-130.

61. Pacheco, P.; Aguilar-Støen, M.; Börner, J.; Etter, A.; Putzel, L.; del Carmen Vera Diaz, M. Landscape transformation in tropical Latin America: Assessing trends and policy implications for REDD+. Forests 2011, 2, 1-29. 
62. Borsy, P.; Sosa, E.V.; Molinas, W.; Cuellar, C.L.; Enciso, P. Manejemos Nuestro Bosque: Manual de Manejo de Bosque Nativo en Pequeñas Fincas, Proyecto Manejo Sostenible de Recursos Naturales; MAG/KfW/GTZ: Asunción, Paraguay, 2010; p. 46.

63. Hagen, R. Evaluation des Projets Pilotes d'Aménagement des Forêts Naturelles A Madagascar; United States Agency for International Development: Antananarivo, Madagascar, 2001.

64. Kothari, A.; Camill, P.; Brown, J. Conservation as if people mattered: Policy and practice of community-based conservation. Conserv. Soc. 2013, 11, 1-15.

65. Bidaud, C. REDD+, Un Mécanisme Novateur? Le cas de la forêt de Makira à Madagascar. Rev. Tiers Monde 2012, 211, 111-130.

66. McConnell, W.J.; Sweeney, S.P. Challenges of forest governance in Madagascar. Geogr. J. 2005, $171,223-238$.

67. Casse, T. The international debate on forest management transfer and our contribution. Les Cah. d'Outre-Mer 2012, 257, 11-46.

\section{Appendix}

Appendix 1. Questions posed to forest owners, managers and experts engaged in forest restoration in Paraguay and Madagascar.

1. Can you point to specific factors influencing your (others') decisions to restore or not forests in your country?

2. What is your/the primary motivation to restore forests?

3. What are the most common species used for restoration? What determines the choice of species for restoration/reforestation?

4. What determines the area chosen for restoration/reforestation?

5. What approaches/species are commonly used for restoration?

6. What could encourage you to restore more?

7. What are the challenges faced with forest restoration?

8. What are opportunities for forest restoration?

9. How successful would you rate forest restoration (in your area/country)? And on what are you basing your judgment?

10. How is the restored area currently managed/governed and how will it be managed/governed in the future? Who are the main actors in forest restoration management/governance and what is the relationship between these actors? What are the key challenges or opportunities with respect to governance of these areas?

(C) 2014 by the authors; licensee MDPI, Basel, Switzerland. This article is an open access article distributed under the terms and conditions of the Creative Commons Attribution license (http://creativecommons.org/licenses/by/3.0/). 